DOI: https://doi.org/10.32838/2523-4803/71-4-17

UDC $336 ; 336.01 ; 336.11 ; 336.741 .28 ; 336.7$

\title{
Mammad Mammadov
}

$\mathrm{PhD}$,

Institute of Economy of Azerbaijan National Academy of Sciences

\section{Mammad Mammadov}

Інститут економіки Азербайджанської національної академії наук

\section{THE ROLE OF THE INVESTMENT CLIMATE IN SOLVING THE PROBLEM OF HUMAN RESOURCE FORMATION IN THE TAX SYSTEM OF THE REPUBLIC OF AZERBAIJAN}

The issue of creating a favorable tax environment in any country plays an important role in solving the problem of human resource development. Foreign investors are more interested in the stability and evolution of the tax system, which allows them to predict their activities in the long run, rather than tax benefits and privileges. The main purpose of the state investment policy is to ensure the renewal of fixed assets and the reconstruction of production through the application of scientific and technical achievements. The formation of a favorable investment climate, the effective use of attracted domestic and foreign investment resources in the priority areas of the national economy is one of the urgent problems of the Azerbaijani economy. Enterprises become increasingly aware that proper investment into human resources can have a significant impact on their performance, which of course also affects their competitiveness. The corporate culture exactly offers the greatest source of competitive advantage of enterprises. Continual adaptation to changing market conditions attracts businesses to invest their energy and finance to staff by improving their competencies.

Key words: tax system, human resources, investment, investment policy, human capital.

Introduction. Developed economies are economies that have achieved high levels of industrialization and material prosperity. Therefore, the tax policy pursued in these countries differs significantly from the tax policy in the least developed countries. Income tax dominates the tax system of highly developed, industrialized market economies. General income tax consists of personal income tax and income tax of legal entities or organizations. In highly economically industrialized countries, the share of income tax in total tax revenues varies from 55 to $60 \%$ in different countries. The rest of the tax revenue is deducted from expenses. The share of tax revenues in the tax revenues of the United States is $75 \%$, which is the highest in the world. In these countries, the main part of income tax is personal income tax. Taxpayers' income from various sources is collected and accrued interest income is applied to the collected income.

An important aspect for the national economy is the formation of an investment climate in terms of ensuring the growth of production. This process does not happen spontaneously. Market automation is not able to solve this problem, and appropriate steps can play an important role in the purposeful intensification of investment processes. Another important factor is financial stability. Achieving this stability depends to a large extent on the formation of investment resources and ensuring the efficiency of investment projects and the conditions of a favorable investment climate in general [1]. The organization of the investment climate largely depends on the activity of the private sector, its special weight, the intensity of relations, the level of development of small and medium enterprises.

Analysis of recent research and publications. In order to achieve the goals and objectives of the article, Azerbaijan's experience in this field and research on related issues were studied. Thus, the issues of assessing the impact of the tax regime on the investment environment were discussed by Azerbaijani scientists Hasanli M., Bagirov D., Khankishiyev B., Kalbiyev Y., Rzayev I., Maharramov R. and investigated by others.

Formulation of the aim of the article. To research the role of the investment climate in solving the problem of human resource formation in the tax system of the Republic of Azerbaijan.

Main material. As a rule, when talking about the investment climate in Azerbaijan, its favorable geopolitical and geographical position, highly qualified human resources, rich natural resources are highlighted. In fact, these are only prerequisites for creating a favorable investment climate, and in the absence of an effective approach, this wealth can be a source of serious problems for the country's economy and even the country as a whole. In the initial approach to these problems, the following can be attributed [2]:

- Conflict of interests of states interested in the region;

- unilateral expansion of the national economy, the threat of the country becoming a raw material supplement for major powers, etc. 
The land reform implemented in Azerbaijan, unlike in many former Soviet republics, has created an objective basis for a favorable investment climate. Investments are classified as autonomous and industrialized due to the nature of their formation. Autonomous investments, regardless of interest rates or national income levels, are usually driven by external factors.

These include, above all, investments related to technical progress, strengthening positions in foreign markets, population growth and other factors. These investments stimulate economic growth. Development can be considered dynamic if the induced investments resulting from increasing incomes are an organic continuation of those impulses. In other words, induced investment plays the role of accelerator as a function of GDP (gross domestic product) growth $[2 ; 3]$.

Particular attention is paid in the relevant literature to assessing the impact of economic growth on the parts of investments that differ in nature and purpose. There are even those who consider autonomous investments to be the main reason for the periodic increase or decrease in production. As for the concept of investment activity, it can be said that in the most general case, it can be considered as a combination of investment and practical activities carried out for the realization of these funds. Investment in the creation of fixed assets and large-scale reproduction is carried out in the form of capital investment. This is called fixed capital investment.

The main functions performed by investments in economic systems are to ensure the growth and qualitative improvement of fixed capital at the micro and macro levels; support for progressive structural change; realization of production efficiency at different levels on the basis of scientific and technical achievements. The subjects of investment activity are different in composition. This structure includes: investors, customers, contractors, users of investment facilities, shippers, etc. Legal entities should be mentioned separately in this list. Legal entities include banks, insurance and intermediary organizations, and investment funds.

Funds directed to entrepreneurship and other activities, targeted bank deposits, shares and other securities, property, intellectual property and other bank investments can be considered.

Sometimes the investment activity of banks includes all operations on the placement of funds for a certain period of time in order to earn income, in other words, all active operations of banks are considered investments. In fact, this approach is incorrect. Thus, assets such as funds in the central bank cannot be considered an investment because they do not work for the bank [3].

Customers can be investors or individuals and legal entities authorized by investors. These persons participate in the implementation of the investment project and, unless otherwise provided in the contract, other participants do not interfere in entrepreneurial activities. Mistakes in investment are, in some cases, related to information problems. "Wrong" leads to the scattering of investment resources, resulting in the "sinking" of funds in projects that do not lead to projected economic growth. Therefore, research aimed at studying the conjuncture should be considered one of the main factors determining the efficiency of investment [2].

The dynamics of the investment market also determines its efficiency. It is known that investments flow from declining enterprises (sectors) to more profitable enterprises when other conditions are equal. Therefore, it is necessary to ensure that investments in production are always risky and cover a long period of time. For example, an environment should be created where the return on investment in production is higher than alternative investments (bank deposits, jewelry, etc.) [1].

Investors have equal rights to carry out investment activities in accordance with the principles of a free economy. The investor is to some extent free to determine the volume, direction and efficiency of the investment. Thus, the investor can attract legal entities and individuals necessary for the implementation of the investment in the form of spending through contracts and competitions. Whether it is its own funds or borrowed funds, the investor almost always exercises the right to demand the targeted use of the invested funds. The following are accepted as objects of investment activity [2]:

- securities (stocks, bonds, etc.);

- newly created and modernized fixed assets and working capital in all sectors of the economy;

- purposeful money deposits;

- scientific and technical products and other objects of property;

- property rights and intellectual property rights.

The investment climate can be combined into three groups: socio-political, economic-social and legalorganizational. In this regard, the socio-political factor is the domestic and foreign political regime of the country, the stability of the social situation; Socio-economic factors include the level of economic development (or potential opportunities for economic development), the level of economic growth and its prospects, the state of inflation, the strength and exchange rate of the national currency, taxation, customs and trade regimes, market infrastructure development, purchasing power, labor force market situation (its price, composition), level of infrastructure development, etc.; Legal support and organizational measures may include legal normative acts applied in the country and organizational and propaganda measures to attract investment.

Direct and portfolio investments are more important in investment. The distribution of capital for investment purposes is of great practical importance in the field of investment. According to this division, there are direct investments and portfolio investments.

Direct investment is a capital investment that allows the investor to control the object in which the capital is invested. Direct investments are made in order to gain long-term economic interest. These investments are mainly related to private entrepreneurial capital. 
Portfolio investment is capital invested in foreign securities. These investments do not give the investor real control over the invested object.

It is not right to think about the development of the country's economy just by looking at the growth of investment. Investment is a broad concept, and it is important to know what direction to take. Thus, determining the use of the portfolio, direct, domestic or foreign investment may be a priority. As a country, it is possible to attract investment in the wrong areas that will lead the country to decline, not development [4].

Conclusions. In today's dynamic times of intensifying globalisation, when many countries are hit by the financial crisis, a company should monitor new trends in their business environment. Managers make daily permanent decisions to develop an effective strategy that will help them to succeed in a highly competitive environment. It is more and more true that in order to succeed, companies should provide and keep quality human resources [4]. It is generally understood that times when tangible assets were the most important assets of a business are long gone. Therefore, many businesses now focus on the knowledge and skills of their employees and the company as a whole, and these often become a source of their competitive advantage. Companies now invest in human resources and significant financial resources and seek appropriate opportunities for streamlining the development of their employees' potential. Human capital plays a crucial role in increasing the productivity and output of an organisation [5]. It is involved in the creation of the market value of the company and also represents the most valuable source of company. This analysis of selected company proved the effectiveness of investment in human resources through the use of measurable and immeasurable indicators of efficiency of investment in human resources. The results confirmed that the wage system in the analysed company is set up so that the amount of wages is based on the turnover of the enterprise. The business has thus few possibilities to change this fact; however, it can focus on improving the system of corporate benefits, which can ensure retention and loyalty of employees in the company. For that reason, we recommend the company to obtain from their employees feedback determining whether the business benefits are set up to act as an incentive and arouse employees' interest. In order to prevent unwelcomed turnover, a company should try to analyse and identify the reasons for employees' dissatisfaction and for leaving of former employees. If a company is aware of reasons for dissatisfaction, it can evaluate and then implement necessary changes in system of rewarding and motivation of employees, which may prevent further loss of human capital. Labour productivity growth, both in sales and value added, is a key for the performance of the company because it leads to savings in expenditure of labour and labour costs. Based on the research conducted, we recommend to the analysed company to focus on examining the relationship between labour productivity and rewarding schemes and to pay special attention to the needs and specifics of human capital, because it is human capital in the company that is able to create value. Human capital value added (HCVA) had an upward tendency, which means that human resources create added value effectively. It is important for the company to pay special attention to this indicator because its rank indicates the overall efficiency of utilisation of human resources (value added by labour), and therefore we can conclude on the basis of these results that the company uses its human resources effectively. The company is further advised to regularly monitor the development achievements of HCROI, because this indicator is a key method of measuring human capital in the company. The enterprise expects that investments in its employees shall be returned, although long-term nature of the return on investment in human capital must be taken into account. What we consider to be a satisfactory outcome of this research is that when evaluating motivation in both the compared groups, respondents responded to the same 10 most important motivation factors, which more or less affect the satisfaction, motivation and performance of the human resources of the company. Based on the gained knowledge, we recommend the company to focus on (within their strategy of investing in human resources) the examined motivation factors that enable higher and more effective contribution from investments in human capital company. Finally, in order to efficiently use human resources in the analysed company, increase of employees' awareness about the system of corporate benefits and the possibilities for their further education and development would help to achieve the best results. All these items can significantly increase employees' satisfaction, their motivation and especially their work performance, which consequently positively translate into greater efficiency, prosperity and competitiveness of the company itself.

\section{References:}

1. Kalbiyev Y.A. (2005) Problems of fiscal policy and regulation of the national economy. Monograph. Baku.

2. Allahverdiyev H. (2002) "State regulation of the economy" textbook. Baku, "Nasir".

3. Yutkina T.F. (2002) Taxes and Taxation. Moscow: "Infra-M".

4. Mammadov F.A., Musayev A.F., Sadigov M.M., Rzayev Z.H. (2010) Taxes and taxation. Baku.

5. Republic of Azerbaijan Ministry of Econom. Available at: www.economy.gov.az. 


\section{РОЛЬ ІНВЕСТИЦІЙНОГО КЛІМАТУ У ВИРІШЕННІ ПРОБЛЕМИ ФОРМУВАННЯ КАДРІВ} У ПОДАТКОВІЙ СИСТЕМІ АЗЕРБАЙДЖАНСЬКОЇ РЕСПУБЛІКИ

Питання створення сприятливого податкового середовища в будь -якій краӥні відіграє важливу роль у вирішенні проблеми розвитку людських ресурсів. Іноземних інвесторів більше цікавить стабільність та еволюція податкової системи, щзо дозволяє їм прогнозувати свою діяльність у довгостроковій перспективі, а не податкові пільги та пільги. Основною метою держсвної інвестиційної політики є забезпечення оновлення основних фондів та реконструкиії виробниитва шляхом застосування науково-технічних досягнень. Формування сприятливого інвестиційного клімату, ефективне використання залучених внутрішніх та іноземних інвестиційних ресурсів y пріоритетних сферах національної економіки є однією з актуальних проблем економіки Азербайджану. Підприємства все більше усвідомлюють, щзо належні інвестииї в людські ресурси можуть мати значний вплив на їх роботу, що, звичайно, також впливає на їх конкурентоспроможність. Корпоративна культура $\epsilon$ найбільшим джерелом конкурентних переваг підприємств. Постійна адаптація до мінливих ринкових умов залучає підприємства інвестувати свою енергію та фінанси персоналу шляхом покращення своєї компетенції. Підприємства покрашують свої людські ресурси, а отже, збільшують свої психологічні та професійні активи, інвестуючи в людський потенціал окремих людей, покрамуючи їх навички та компетентність. Існують різні способи інвестування в людські ресурси. Підприємства можуть інвестувати у загальний людський капітал, тобто інвестииї у спеціальне або загальне навчання, що дає змогу здобувати загальні знання, які можна використовувати у різних компаніях. Це призводить до більш високого очікуваного повернення інвестииій у майбутньому. Другий варіант інвестування в людські ресурси - ие інвестування в конкретний людський капітал. Зокрема, ие інвестування у вдосконалення конкретних компетениій та навичок для певної роботи. Ця форма інвестицій є мени ризикованою з точки зору плинності персоналу, оскільки використання певних знань рідше буде використовуватися в інших компаніях. Стаття приходить до думки, щзо всі ці пункти можуть значно підвищити задоволеність працівників, їх мотивацію і особливо продуктивність роботи, щзо, отже, позитивно перетворюється на підвищення ефективності, процвітання та конкурентоспроможності самої компанії.

Ключові слова: податкова система, людські ресурси, інвестиції, інвестиційна політика, людський капітал.

\section{РОЛЬ ИНВЕСТИЦИОННОГО КЛИМАТА В РЕШЕНИИ ПРОБЛЕМЫ ФОРМИРОВАНИЯ КАДРОВ В НАЛОГОВОЙ СИСТЕМЕ АЗЕРБАЙДЖАНСКОЙ РЕСПУБЛИКИ}

Вопрос создания благоприятной налоговой среды в любой стране играет важную роль в решении проблемы развития человеческих ресурсов. Иностранных инвесторов больше интересует стабильность и развитие налоговой системы, которая позволяет им прогнозировать свою деятельность в долгосрочной перспективе, а не налоговые льготы и льготы. Основная иель государственной инвестиционной политики - обеспечение обновления основных фондов и реконструкции производства за счет применения достижений науки и техники. Формирование благоприятного инвестициионного климата, эффективное использование привлеченных внутренних и внешних инвестиџионных ресурсов в приоритетных сферах наџиональной экономики является одной из актуальных проблем экономики Азербайджана. Предприятия все больше осознают, что правильные вложения в человеческие ресурсы могут существенно повлиять на их производительность, что, конечно, также влияет на их конкурентоспособность. Корпоративная культура как раз предлагает самый большой источник конкурентного преимущества предприятий. Постоянная адаптация к изменяющиися рыночным условиям привлекает компании вкладывать свою энергию и финансы в персонал за счет повышения их компетенций. В статье делается вывод о том, что все эти элементы могут значительно повысить удовлетворенность сотрудников, их мотивацию и особенно их производительность труда, что, следовательно, положительно сказывается на большей эффективности, процветании и конкурентоспособности самой компании.

Ключевые слова: налоговая система, человеческие ресурсы, инвестиции, инвестиционная политика, человеческий капитал. 